\title{
Enhancement of Laccase Production by Optimizing the Cultural Conditions for Pleurotus sajor-caju in Solid-State Fermentation
}

\author{
Shradhdha Sharma (iD) and Duggirala Srinivas Murty* \\ Department of Biogas Research and Microbiology, Gujarat Vidyapith, Sadra - 382 320, Gandhinagar, \\ Gujarat, India.
}

\begin{abstract}
Nowadays, a lot of interest has been given to the development of cost-effective and efficient enzyme production technologies. Laccase enzymes are widely used in biotechnological, environmental and industrial sectors. Due to the cost-effectiveness of the solid-state fermentation (SSF) process, it is widely used to produce a broad range of biological products. In this study, optimization of moisture content, temperature, $\mathrm{pH}$, and inoculum size were studied to enhance laccase production ability of Pleurotus sajor-caju in SSF by using One Factor At Time (OFAT) and Response Surface Methodology (RSM). OFAT was used as a baseline study for deducing the experimental design of RSM. The highest production of laccase enzyme $(1450 \mathrm{U} / \mathrm{g})$ by Pleurotus sajor-caju on wheat straw was observed at $26^{\circ} \mathrm{C}, 6.0 \mathrm{pH}$, $\mathbf{7 2 . 5} \%$ moisture content, $7.5 \%$ inoculum size, $1 \%$ fructose and $0.5 \%$ peptone. Unlike the conventional inoculum preparation method, here the inoculum was generated by the spawning method for SSF. The molecular weight of partially purified laccase from Pleurotus sajor-caju was estimated to be around $62 \mathrm{~K}$ Da using SDS PAGE. The activity staining of laccase was observed as a zymogram on Native PAGE using $A B T S$ as a substrate. Lignin degradation of wheat straw and its structural disruption due to laccase was observed by Scanning Electron Microscopy (SEM).
\end{abstract}

Keywords: Ligninolytic enzymes, Response Surface Method (RSM), Scanning Electron Microscopy (SEM)

*Correspondence: dsrinivasmurty@gujaratvidyapith.org; +91-9824268626

(Received: October 31, 2020; accepted: May 24, 2021)

Citation: Sharma S, Murty DS. Enhancement of Laccase Production by Optimizing the Cultural Conditions for Pleurotus sajor-caju in Solid-State Fermentation. J Pure Appl Microbiol. 2021;15(2):958-967. doi: 10.22207/JPAM.15.2.54

(C) The Author(s) 2021. Open Access. This article is distributed under the terms of the Creative Commons Attribution 4.0 International License which permits unrestricted use, sharing, distribution, and reproduction in any medium, provided you give appropriate credit to the original author(s) and the source, provide a link to the Creative Commons license, and indicate if changes were made. 


\section{INTRODUCTION}

The use of agro-industrial wastes for solid-state fermentation (SSF) is a better option than burning it. The annual, global agricultural production is measured to be approximately 3.8 billion metric tons of total crop residues ${ }^{17,36}$. Lignin is the second most rich carbon source; it is amorphous and possesses a complex threedimensional structure containing phenylpropanoid subunit which is the limiting factor for biomass conversion processes ${ }^{18}$.

Agricultural residues containing lignin, hemicellulose, and cellulose are not only abundantly available but also cost-effective in $\mathrm{SSF}^{32}$. Utilization of agro-residues in SSF for enzymes are the most practical and economical method for the bioconversion of agro-based lignocellulosic biomass into value added products ${ }^{4,30}$.

The Solid State Fermentation is performed in a small amount of free-flowing water on an innate substrate as a solid support. The focused study of SSF is to achieve high substrate concentration and maintaining a close contact of microorganisms with solid support ${ }^{3}$. The conditions in SSF are very near to the natural habitat of microorganisms, especially for fungi. Substrate availability, presence of carbon and nitrogen sources is the most important criteria for cost effective production in solid state fermentation. Fungal hyphae form a rug on the substrate and break down enzymes and secondary metabolites in fungal $\mathrm{SSF}^{26,27}$.

Basidiomycetes oxidize phenolics to give phenoxy radicals and quinines, thus they efficiently degrade lignin compared to ascomycetes and deuteromycetes ${ }^{8}$. Basidiomyceteous fungi, especially white rot fungi widely are used in the production of ligninolytic enzymes like laccase $(\text { EC 1.10.3.2) })^{42}$, lignin peroxidase (EC 1.11. 1.14) ${ }^{9}$, manganese peroxidase (EC 1.11.1.13) $)^{25}$, and versatile peroxidases (EC 1.11.1.16) ${ }^{21}$ in solid state fermentation. In many previous studies, the optimization and production of laccase has been shown using white rot fungi ${ }^{6,16,5,23,39}$ but to our knowledge, there have been no studies on optimization of laccase production from Pleurotus sajor-caju in solid state fermentation on wheat straw.

Laccase has been used for intensive research because of its broad substrate specificity, synthesis of low molecular weight cofactors, and its stability in the external environment. As laccase can oxidize various toxic and non-toxic substances, it is applicable in various fields such as food biotechnology, enzymes, mushrooms, amino acids, flavours, bioprocess, bioleaching, bio pulping, animal feed and industrial wastewater treatment. Pre-digestion of lignin, hemicellulose and cellulose with ligninase, cellulase and xylanases may possibly convert the lignin containing substrate into animal feed with higher digestibility and ruminant quality ${ }^{38}$.

Optimization of temperature, $\mathrm{pH}$, substrate selection, and carbon to nitrogen ratio is required to improve laccase production ${ }^{31}$. Statistical methods are used such as Response Surface Method (RSM) is especially where the valuable significant results are observed. Empirical modelling system which estimate the correlation linking a set of variables present in RSM. Results can be controlled experimentally and to study their effect on response ${ }^{33,34}$.

This study focused on laccase production using Pleurotus sajor-caju on wheat straw and optimization of different factors for enhancing laccase production in solid state fermentation.

\section{MATERIALS AND METHOD}

\section{Culture collection and maintenance}

Pleurotus sajor-caju was procured from the National Collection of Industrial Microorganisms (NCIM accession no.-1133), Pune, Maharashtra, India. The culture was preserved onto Potato Dextrose Agar (PDA) slant at $4^{\circ} \mathrm{C}$ and regularly sub-cultured on a fresh medium.

\section{Inoculum (Spawn) preparation for laccase} production

The spawns were prepared using sterile sorghum grains as substrate in $250 \mathrm{~mL}$ Erlenmeyer flask. Pleurotus sajor-caju was inoculated into the flask and incubated at $24 \pm 2^{\circ} \mathrm{C}$ for 7 days.

Culture condition for laccase production under solid state fermentation

Various lignocellulosic substrates i.e. rice bran, groundnut gotter, paddy straw, wheat straw, sorghum straw, de-oiled rice bran, bajra straw, sorghum hay and maize straw were optimized for the laccase production in solid state fermentation. Optimization was done using $100 \mathrm{~g}$ SSF system in sterile polyvinyl containers with cotton plug for exchange of gases. The moistening agent 
was used as described by Tein and Krick, 1988. The moistening agent contained(g/L): Glucose; 10, Yeast extract; $5, \mathrm{KH}_{2} \mathrm{PO}_{4} ; 0.6, \mathrm{MgSO}_{4} ; 0.5$, $\mathrm{K}_{2} \mathrm{HPO}_{4} ; 0.4, \mathrm{CuSO}_{4} .5 \mathrm{H}_{2} \mathrm{O} ; 0.25, \mathrm{FeSO}_{4} .7 \mathrm{H}_{2} \mathrm{O}$; $0.05, \mathrm{MnSO}_{4}$ and $\mathrm{ZnSO}_{4} ; 0.001$. Each system was inoculated with $5 \%(\mathrm{w} / \mathrm{w})$ spawn and incubated at $24 \pm 2{ }^{\circ} \mathrm{C}$ for 14 days. Wet fermented biomass ( 1 $\mathrm{g}$ from a pooled sample) was collected on every alternate day by spatula and the crude enzyme was extracted into $50 \mathrm{~mL}$ sodium phosphate buffer $(\mathrm{pH} 6)$. The extract of enzyme was centrifuged at $12000 \mathrm{~g}$ for $20 \mathrm{~min}$ at $4^{\circ} \mathrm{C}$ and the supernatant was used to determine laccase activity as previously described by Niku- Paavola, 1990.

Optimization of physicochemical parameters to enhance the laccase production

The physico-chemical factors are most critical for the higher laccase production from Pleurotus sajor caju. The SSF was conducted in $100 \mathrm{~g}$ system as described above. One of the factors was altered for optimization and all levels were studied separately.

The optimization of parameters such as moistening agent $(50,60,70,80,90 \%), \mathrm{pH}$ $(4,4.5,5,5.5,6)$, Temperature $\left(20,24,28,32^{\circ} \mathrm{C}\right)$ and Inoculum size $(2.5,5,7.5,10 \% \mathrm{w} / \mathrm{w})$ were studied by OFAT (One Factor at A Time) as a base line study for optimization using Response Surface Methodology (RSM) design.

Various carbon ( $1 \% \mathrm{w} / \mathrm{v})$ and Nitrogen sources $(0.5 \% \mathrm{w} / \mathrm{v})$ such as fructose, sucrose, xylose, maltose, dextrose, Peptone, Urea, Ammonium nitrate and Ammonium sulphate were augmented to wetting agent.

\section{Analysis by RSM}

The physicochemical parameter that had influencing effect on the production of laccase were identified using the OFAT method, and levels of each parameter were chooses in RSM design using Central Composite Design (CCD) in Design Expert software (Design Expert, Stat-Ease Inc, version 8.0.6.1). Five different levels of every factor were experimented in set of 30 experiments. The highest significance of each parameter acquired from optimization using OFAT was considered as the zero value in RSM. The minimum and maximum ranges for the parameters were; Factor: 1 (Temperature) $24-28^{\circ} \mathrm{C}$, Factor: $2(\mathrm{pH})$ 4-7, Factor: 3 (Moisture content) $65-80 \%$ and Factor: 4 (Inoculum) $5-10 \%(w / w)$. Experiments of all the permutations were performed in $100 \mathrm{~g}$ SSF system. The arithmetical association of the selfdetermining factors and the response (laccase activity) were estimated by the second-degree polynomial equation.

$$
Y=\beta_{0}+\beta_{1} A+\beta_{2} B+\beta_{3} C+\beta_{4} D+\beta_{11} A^{2}+\beta_{22} B^{2}
$$

$+\beta_{33} C^{2}+\beta_{44} D^{2}+\beta_{12} A B+\beta_{13} A C+\beta_{14} A D+\beta_{23} B C+$ $\beta_{24} B D+\beta_{34} C$

$\mathrm{Y}$ is the measured response (Laccase $\mathrm{U} / \mathrm{g}$ )

$A, B, C$ and $D$ are independent factors, $\beta_{1}, \beta_{2}, \beta_{3}, \beta_{4}$ are linear coefficients, $\beta_{11}, \beta_{22}, \beta_{33}, \beta_{44}$ are quadric coefficients and $\beta_{12}, \beta_{13}, \beta_{14,}, \beta_{23}, \beta_{24}, \beta_{34}$ are cross product coefficients of the model. The model significant terms was measured by utilizing Fisher's ' $F$ ' test and its equivalent probability ' $p$ '. Coefficient of the verifying $R 2$ and regulated $R^{2}$ predicted the model's statistically.

\section{Laccase enzyme assay}

Laccase production was estimated spectro-photometrically as mentioned by Niku-Paavola, $1990^{28}$ with 2, 2 - azino bis-3ethylbenzthiozoline-6-sulfonic acid (ABTS) as substrate, oxidation of ABTS $\left(\varepsilon=36,000 \mathrm{~cm}^{-1}\right.$ $\mathrm{M}^{-1}$ ) was observed at $420 \mathrm{~nm}$ with the increase in absorbance. One unit of enzyme activity was calculated as the amount of enzyme required for oxidizing 1 micro mol ABTS per minute.

\section{Partial purification of laccase}

The laccase production by Pleurotus sajorcaju was performed in solid state fermentation using wheat straw as substrate. The optimized condition for laccase production was $\mathrm{pH} 5.5$, wheat straw as substrate, $24^{\circ} \mathrm{C}$, Moisture $70 \%$, Fructose as carbon and peptone as nitrogen source. The enzyme was extracted into the phosphate buffer (pH 6, $200 \mathrm{mM}$ ) and mixture centrifuged at 12000 $\mathrm{g}$ for $20 \mathrm{~min}$ at $4^{\circ} \mathrm{C}$. The supernatant was subjected to ammonium sulphate precipitation ranging from $10-90 \%(w / v)$ in an ice bath. The precipitated protein was collected by centrifugation at $12000 \mathrm{~g}$ for $15 \mathrm{~min}$ at $4^{\circ} \mathrm{C}$ and the pellet was resuspended in minimum volume of sodium acetate buffer $(\mathrm{pH}$ $4.5,100 \mathrm{mM})$. To get the maximum concentration of laccase, precipitated protein was dialyzed overnight in sodium acetate ( $\mathrm{pH} 4.5,100 \mathrm{mM})$ buffer. The size of partially purified laccase enzyme was estimated by using $12 \%$ Sodium Dodecyl Sulphate - Polyacrylamide Gel Electrophoresis (SDS-PAGE). Activity staining of laccase enzyme was carried out in Native PAGE containing $1 \mathrm{mM}$ 
ABTS. After electrophoresis, the gel was incubated in $50 \mathrm{mM}$ sodium acetate buffer $(\mathrm{pH} 4.5)$ at room temperature $\left(26 \pm 2^{\circ} \mathrm{C}\right)$ for 5 hours.

Scanning electron microscopy

SEM was used to characterize the changes in surface morphology of treated and untreated substrate (wheat straw). Samples were prepared by drying the treated and untreated substrate in hot air oven at $50^{\circ} \mathrm{C}$ until constant weight ${ }^{15}$. After drying the samples, scanning electron micrographs were taken on Jeol JSM-6010LA Scanning Electron Microscope.

\section{RESULT AND DISCUSSION Substrate screening}

The solid substrate is used to support fungal development and enzyme production. The selection of substrate plays a crucial role in solid state fermentation for higher productivity and cost effectiveness. Study says that wheat straw was the most suitable substrate for laccase production (820 $\pm 42.1 \mathrm{U} / \mathrm{g}$ ) (Supplementary Figures). So for laccase production and its optimization, wheat straw was used as substrate.

Optimization of physicochemical parameters for laccase production using OFAT

Effect of moisture content

In this study the effect of moisture content on laccase production was the first experiment of OFAT optimization. The other parameters were $24^{\circ} \mathrm{C}, \mathrm{pH} 6$, inoculum $5 \%$, dextrose and yeast extract as carbon and nitrogen source, respectively. The moisture content (Table 1) of SSF was varied from 50 to $90 \%$. The enzyme levels were studied for 14 days. In all the moisture combinations the highest enzyme production was obtained near 10 days. Maximum laccase production (864.9 U/g) was observed at $70 \%$ moisture content on $10^{\text {th }}$ day. According to Bhargav et al. low moisture and poor thermal conductivity of the substrate in SSF makes heat transfer and temperature control difficult ${ }^{3}$. In SSF moisture is responsible for water activity and the availability of nutrients and oxygen is influenced by moisture content. The transportation of nutrients across the cell membrane is dependent upon aqueous state and if the moisture content decreases the cell are deprived of essential nutrients and oxygen ${ }^{12,14}$. The excess moisture content may pose adverse effect by creating anaerobic condition in SSF and thereby reducing the permeability of air through biomass. Patel and Gupte reported optimization of moisture content for laccase production by utilizing Tricholoma giganteum on wheat straw as substrate. They observed higher laccase production at $80 \%$ moisture content ${ }^{29}$.

Table 1. Experimental variables and optimum laccase activity

\begin{tabular}{llll}
\hline Parameters & Variables & Optimum & Laccase Activity (U/g) \\
\hline Moisture Content (\%) & $50,60,70,80,90$ & 70 & $864.9 \pm 15.9$ \\
& & & \\
Temperature $\left({ }^{\circ} \mathrm{C}\right)$ & $20,24,28,32$ & 24 & $908.7 \pm 17.8$ \\
$\mathrm{pH}$ & $4,4.5,5,5.5,6$ & 5.5 & $979.8 \pm 16.3$ \\
Inoculum (\%) & $2.5,5,7.5,10$ & 7.5 & $914.8 \pm 22.8$ \\
Carbon Source & $\begin{array}{l}\text { Xylose, Fructose, Sucrose, } \\
\text { Maltose, Dextrose }\end{array}$ & Fructose & $945.1 \pm 38.5$ \\
Nitrogen Source & $\begin{array}{l}\text { Peptone, Urea, Ammonium } \\
\text { nitrate, Ammonium sulphate, } \\
\end{array}$ & Peast extract & \\
\end{tabular}

Table 2. Factors and their level used for RSM design

\begin{tabular}{|c|c|c|c|c|c|c|c|}
\hline Factors & Name & Units & Minimum & Maximum & Coded low & Coded high & Mean \\
\hline A & Temperature & ${ }^{\circ} \mathrm{C}$ & 22.00 & 30.00 & $-1 \leftrightarrow 24.00$ & $+1 \leftrightarrow 28.00$ & 26.00 \\
\hline B & $\mathrm{pH}$ & & 4.00 & 8.00 & $-1 \leftrightarrow 5.00$ & $+1 \leftrightarrow 7.00$ & 6.00 \\
\hline C & Moisture & $\%$ & 57.50 & 87.50 & $-1 \leftrightarrow 65.00$ & $+1 \leftrightarrow 80.00$ & 72.50 \\
\hline D & Inoculum & $\%$ & 2.50 & 12.50 & $-1 \leftrightarrow 5.00$ & $+1 \leftrightarrow 10.00$ & 7.50 \\
\hline
\end{tabular}




\section{Effect of $\mathrm{pH}$}

The $\mathrm{pH}$ of the medium strongly influences the fungal growth and enzyme production in SSF. Usually higher growth and laccase enzyme production is observed in acidic $\mathrm{pH}^{40}$. In our study the $\mathrm{pH}$ of the minimal salts was ranging as of 4 to 6. As shown in Table 1; at pH 5.5 after 10 days, maximum laccase production $(979.8 \mathrm{U} / \mathrm{g}$ ) was observed. The enzyme production at 4 and $4.5 \mathrm{pH}$ was nearly half of the optimum value.

The variation in $\mathrm{pH}$ of growth medium showed decreased mycelial growth of fungi on the surface of biomass, which can be attributed for change in laccase production. The difference of enzyme production in our study due to the change in $\mathrm{pH}$ from 6 to 4 was 1.94 -fold. In acidic $\mathrm{pH}$, substrate oxidation was increased because of the potential variation among $T_{1}$ phenolic substrate and copper, while the hydroxide anion combined to the $T_{2} / T_{3}$ copper midpoint ${ }^{19}$. In a similar study on laccase production using Pleurotus species, the enzyme production was increased 4 to $5.5 \mathrm{pH}$ range than decline activity was observed till $8 \mathrm{pH}^{1}$. Effect of temperature

All fungi have an optimal temperature range for growth and enzyme production. The optimum temperature varies from strain to strain. At $24^{\circ} \mathrm{C}$ (Table 1) maximum laccase production

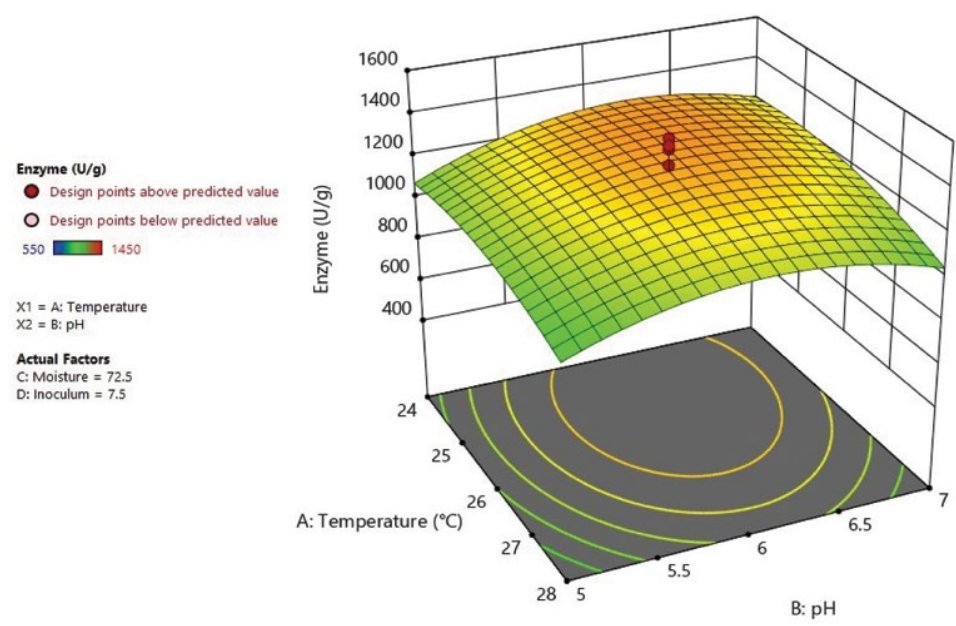

Fig. 1. 3D plot of temperature, $\mathrm{pH}$, inoculum, and moisture optimization for laccase production.
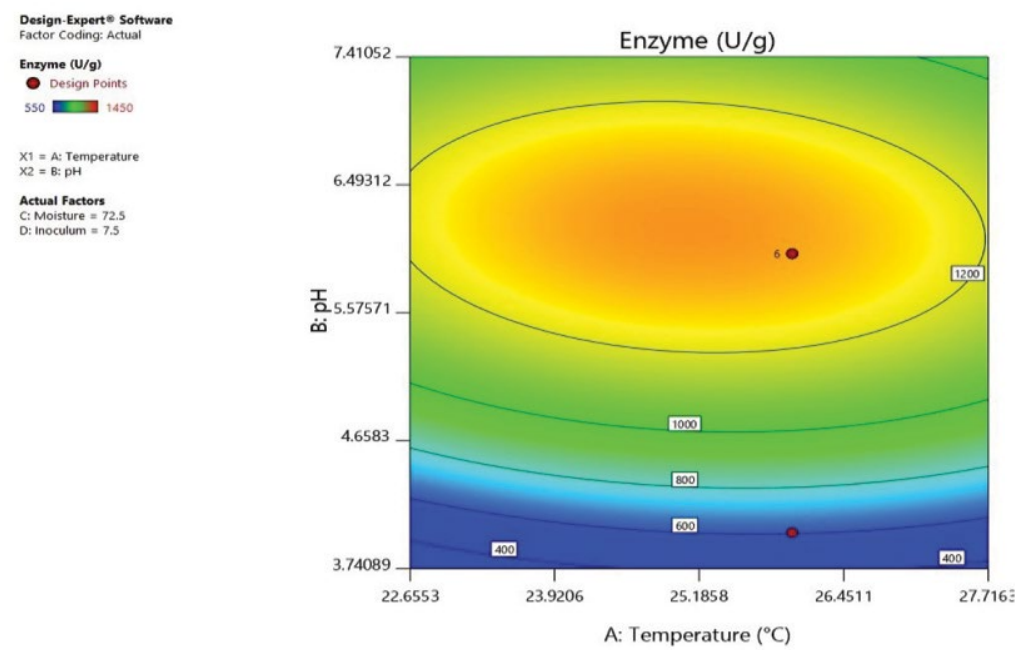

Fig. 2. Contour plot showing optimal zone of parameters for laccase production. 
(908.5 U/g) was observed. According to previous report of Thurston (1994), the higher laccase production is observed between 25 to $30^{\circ} \mathrm{C}^{40}$. Saravankumar et al., (2010) reported maximum laccase production $(44 \mathrm{U} / \mathrm{mL}$ ) by Pleurotus $s p$. at $25^{\circ} \mathrm{C}$ in submerged fermentation ${ }^{35}$. Zadrazil et al. observed decrease in lignolytic enzyme production when temperature goes above $30^{\circ} \mathrm{C}^{44}$.

\section{Effect of inoculum size}

The enzyme production varies with inoculum size as it is dependent on the organism being used and their minimum quantity to ensure that the desired organism is responsible for most of the productivity. The fungi tend to colonize on the solid substratum and show surface growth with even distribution over the surface. The rate

Table 3. Experimental design by RSM and their response

\begin{tabular}{|c|c|c|c|c|c|}
\hline Run & $\begin{array}{l}\text { Temp } \\
\left({ }^{\circ} \mathrm{C}\right)\end{array}$ & $\mathrm{pH}$ & $\begin{array}{c}\text { Moisture } \\
\text { (\%) }\end{array}$ & $\begin{array}{l}\text { Inoculum } \\
(\%)\end{array}$ & $\begin{array}{c}\text { Enzyme } \\
\mathrm{U} / \mathrm{g}\end{array}$ \\
\hline 1 & 26 & 6 & 72.5 & 7.5 & 1416.6 \\
\hline 2 & 28 & 7 & 65 & 5 & 883.3 \\
\hline 3 & 26 & 6 & 72.5 & 7.5 & 916.6 \\
\hline 4 & 26 & 6 & 72.5 & 7.5 & 1450 \\
\hline 5 & 28 & 5 & 65 & 10 & 566.6 \\
\hline 6 & 22 & 6 & 72.5 & 7.5 & 1400 \\
\hline 7 & 24 & 5 & 80 & 10 & 683.3 \\
\hline 8 & 24 & 7 & 65 & 5 & 1291.6 \\
\hline 9 & 28 & 5 & 65 & 5 & 1000 \\
\hline 10 & 24 & 5 & 80 & 5 & 650 \\
\hline 11 & 26 & 8 & 72.5 & 7.5 & 1083.3 \\
\hline 12 & 28 & 7 & 65 & 10 & 550 \\
\hline 13 & 28 & 5 & 80 & 10 & 550 \\
\hline 14 & 24 & 5 & 65 & 5 & 758 \\
\hline 15 & 28 & 5 & 80 & 5 & 583.3 \\
\hline 16 & 24 & 7 & 80 & 5 & 733.3 \\
\hline 17 & 26 & 6 & 72.5 & 7.5 & 1300 \\
\hline 18 & 26 & 4 & 72.5 & 7.5 & 683.3 \\
\hline 19 & 28 & 7 & 80 & 10 & 733.3 \\
\hline 20 & 24 & 7 & 65 & 10 & 550 \\
\hline 21 & 28 & 7 & 80 & 5 & 550 \\
\hline 22 & 26 & 6 & 72.5 & 7.5 & 1400 \\
\hline 23 & 26 & 6 & 72.5 & 12.5 & 766.6 \\
\hline 24 & 26 & 6 & 72.5 & 7.5 & 1329 \\
\hline 25 & 26 & 6 & 57.5 & 7.5 & 1250 \\
\hline 26 & 30 & 6 & 72.5 & 7.5 & 991.6 \\
\hline 27 & 26 & 6 & 72.5 & 2.5 & 983.3 \\
\hline 28 & 26 & 6 & 87.5 & 7.5 & 766.6 \\
\hline 29 & 24 & 7 & 80 & 10 & 633.3 \\
\hline 30 & 24 & 5 & 65 & 10 & 783.3 \\
\hline
\end{tabular}

of colonization is dependent upon the ability of the fungi to spread on the surface ${ }^{10}$. The inoculum size influences the rate of increase in fungal biomass on solid surface and thus enzyme production. Higher laccase production $(914.8 \mathrm{U} / \mathrm{g})$ was observed with $7.5 \%$ inoculum (w/w) followed by 5 and $10 \%$ (Table 1).

\section{Effect of carbon and nitrogen sources}

Carbon and nitrogen are important for growth and enzyme production in solid state fermentation ${ }^{11}$. The additional carbon sources like xylose, sucrose, maltose, fructose and dextrose were studied as inducers for laccase production in solid state fermentation. The highest laccase production $(945.1 \mathrm{U} / \mathrm{g})$ was observed when $1 \%$ fructose ( $w / v$ of wetting agent) was added as carbon source in SSF.

Nitrogen source is important for laccase induction in basidiomycete fungi ${ }^{24}$. Nitrogen is the secondary energy source which is important for the fungal growth and enzyme production. Peptone as a nitrogen source was best suited for highest laccase production (1039.98 U/g) (Table 1). In a similar study, glucose as carbon source and peptone as nitrogen source was reported as most suitable sources for higher laccase production using Pleurotus species ${ }^{1}$.

\section{Optimization of laccase production using RSM}

It is evident from Table 3, Fig. 1 and 2, that the most ideal combination of parameters giving highest laccase production (1450 U/g) was $6 \mathrm{pH}$, $26^{\circ} \mathrm{C}, 72.5 \%$ moisture content and $7.5 \%$ inoculum size. RSM is more specific than OFAT; the Central Composite Design based statistical analysis can explore intra-parametric effects on the response. Coded factors are used to make prediction for the response of each level factor. The equation given below:

$$
\begin{gathered}
Y=1302.06+-61.79 * A+47.93 * B+-93.04 * C+ \\
-76.37 * D+-71.87^{*} A^{2}+-150 * B^{2}+-118.75^{*} C^{2}+ \\
-152.08 * D^{2}+-19.81 * A B+6.23 * A C+10.40^{*} A D+ \\
1.02 * B C+-36.48 * B D+97.90 * C D
\end{gathered}
$$

In the above equation, $Y$ is the response (laccase production $\mathrm{U} / \mathrm{g}$ ) and $\mathrm{A}, \mathrm{B}, \mathrm{C}$ and $\mathrm{D}$ is denoted independent variable factors. In the ANOVA model $p<0.05$ indicates the significance of the model, and $p>0.1$ shows the non significance 
of the model. Model $p<0.05$ for $C, C^{2}, B^{2}$ and $D^{2}$ showed significant for this model. Increased laccase production with different $\mathrm{pH}$ indicated by a positive linear coefficient value for $B$. The positive cross model coefficient of the model temperature: moisture, temperature: Inoculum, $\mathrm{pH}$ : moisture and moisture: inoculum shows increased laccase production. Moisture ratio was important for maximum laccase production followed by inoculum, temperature and $\mathrm{pH}$ revealed by the statistical optimization using RSM. ANOVA showed the coefficient of determination $\left(R^{2}\right)$ value of 0.7059 (a value of $R^{2}>0.6$ indicates suitability of the model) for laccase production. In the model ' $F$ ' value 2.57 and ' $p$ ' value less than 0.005 shows that the model is significant. The laccase production under optimized condition $\left(6 \mathrm{pH}, 26^{\circ} \mathrm{C}, 72.5 \%\right.$ moisture content and $7.5 \%$ inoculum size) was $1450 \mathrm{U} / \mathrm{g}$, which was 1.39 -fold higher than OFAT method.

In similar study, Risdianto et al. optimized laccase production by RSM using white rot fungi and agricultural waste in $\mathrm{SSF}^{34}$. They reported that Marasmius spp. on rice straw could produce

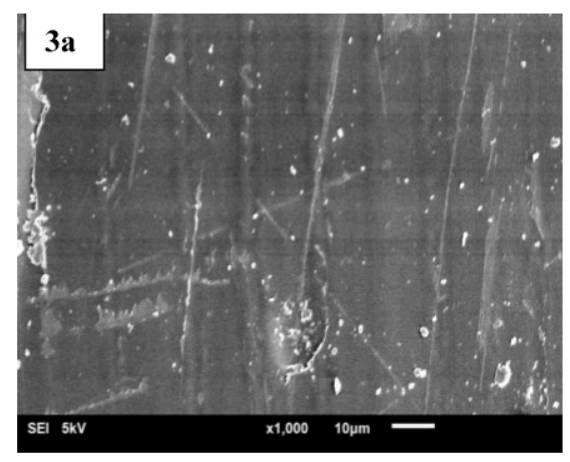

highest laccase activity of $111.1 \mathrm{U} / \mathrm{L}$ on $10^{\text {th }}$ day. $\mathrm{pH}$, temperature, and yeast extract were found to be most significant factors. Sharma et al. used OFAT and RSM for optimization of laccase production from Ganoderma leucidum in SSF using wheat bran as substrate ${ }^{37}$. Bagewadi used statistical approaches like RSM to optimize laccase $(510 \mathrm{U} / \mathrm{g})$ production from Trichoderma harzianum in SSF. Wheat bran and yeast extract were found to be most influencing factors for laccase production². Partial purification of laccase from SSF using Pleurotus sajor caju

The crude enzyme was extracted and purified for SDS and zymogram i.e., activity staining. As shown in Fig. 4, the molecular weight of laccase obtained from Pleurotus sajor-caju was approximately $62 \mathrm{~K} \mathrm{Da}$ (Fig. 4a, Lane 2), for activity staining, ABTS was used as the substrate for laccase (Fig. 4b). Development of Green colour spot in the white background of gel shows that the monomeric laccase was present in the partially purified enzyme.

In a similar study, laccase production in submerged fermentation using Pleurotus

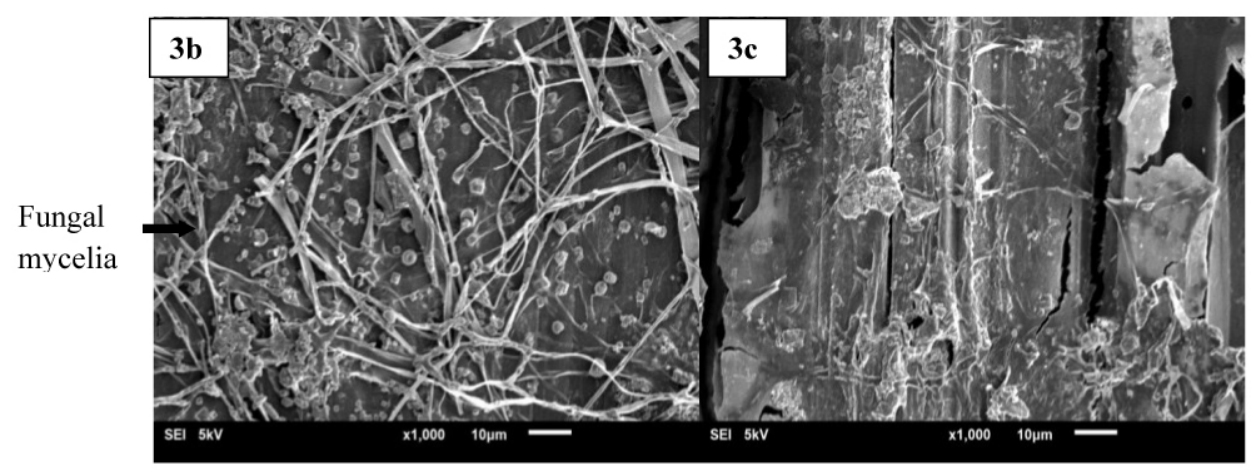

Fig. 3. Scanning electron microscope image (3a) Untreated wheat straw (3b) Mycelial growth on wheat straw (3c) Washed wheat straw after treatment 


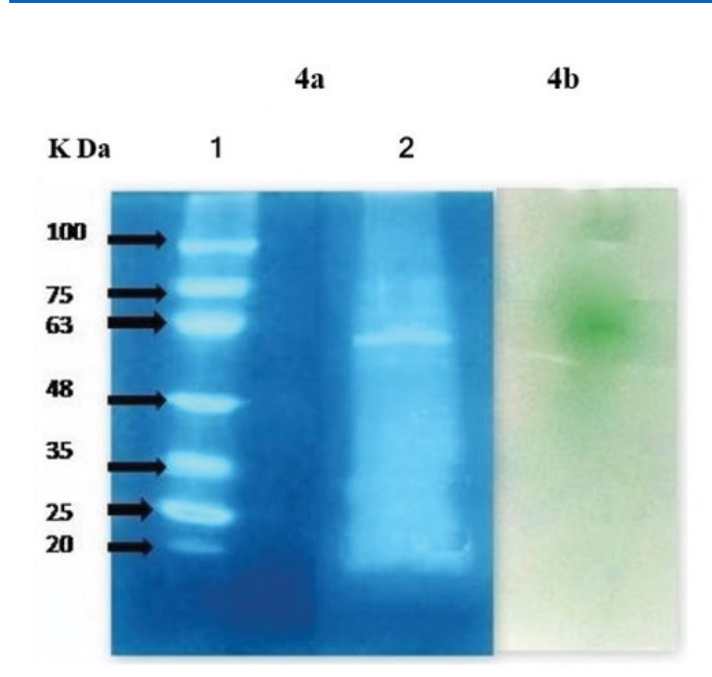

Fig. 4. SDS PAGE and zymogram of laccase enzyme using Pleurotus sajor-caju 4a. Lane 1: molecular weight marker (K Da), Lane 2: partially purified laccase $\mathbf{4 b}$. Activity staining of laccase in Native PAGE shows green colour development with ABTS.

ferulae was carried out and molecular weight of laccase and the presence of active laccase were studied by SDS PAGE and Native PAGE zymogram, respectively. A $66 \mathrm{~K}$ Da laccase and single isoform of active laccase as green coloured spot was shown in zymogram?.

\section{Scanning electron microscope (SEM)}

SEM image shown in Fig. 3, reveals morphological and structural variations in biomass arising during SSF. As shown in Fig. 3a, the untreated wheat straw has an intact cell wall and smooth surface. The wheat straw was fermented with Pleurotus sajor-caju for laccase production in SSF and lignin degradation was confirmed by SEM. The fungal hyphae penetrate the cells and attack the parenchyma tissue as it supports the fungal growth with available nutrients. In Fig. 3b, wheat straw can be seen covered with fungal mycelia. When the treated wheat straw was thoroughly washed with distilled water the fibres of treated sample (Fig. 3c) clearly showed appearance of deteriorated rough surface. The treated wheat straw appeared to have formation of pores, grooves, cracks, disruption of surface and was more conspicuous, than untreated sample. The enhanced porosity further exposes the cellulosic portion for efficient hydrolysis.
Vivekanand et al. reported laccase production on wood pulp in SSF using Aspergillus fumigatus. In their study SEM image showed rougher surface indicating the process of peeling with more exterior fibrillation ${ }^{43}$. Liew et al. reported SEM images of biologically treated wood chips with $T$. versicolor, $P$. coccineus, Daedalea $s p$. and Phellinus $s p$. to show the degradation mechanism of lignin ${ }^{22}$.

\section{CONCLUSION}

This study explored the ability of Pleurotus sajor-caju in solid state fermentation for laccase production using cost effective and easily available agro-residues. To the best of our knowledge there is scarce or no literature available on laccase production using Pleurotus sajor caju. Selection of wheat straw as substrate for laccase production in SSF was carried out from a pool of nine different biomasses such as rice bran, groundnut gotter, paddy straw, wheat straw, sorghum straw, de-oiled rice bran, bajra straw, sorghum hay and maize straw. Various physicochemical parameters such as temperature, $\mathrm{pH}$, inoculum size and moisture content were optimized by applying OFAT and RSM for enhancing laccase production in SSF using Pleurotus sajor-caju and wheat straw as substrate. The optimum conditions for laccase production (1450 U/g) were $\mathrm{pH} 6,26^{\circ} \mathrm{C}$, moisture $72.5 \%$ and inoculum size $7.5 \%$. Initially, the laccase production during screening of biomass was $820 \mathrm{U} / \mathrm{g}$ in SSF, after optimization using OFAT and RSM, the laccase production increased by 1.77 -fold. The effect of laccase produced in SSF on delignification of wheat straw was observed by SEM. The treated biomass clearly showed appearances of pores, cracks, and disrupted surface to indicate delignification of wheat straw. The molecular weight of partially purified laccase enzyme was determined by SDS PAGE, which was approximately $62 \mathrm{~K} \mathrm{Da}$. The presence of active laccase in partially purified enzyme was confirmed by zymogram. The laccase activity was observed using ABTS as a substrate in Native PAGE. Green colour development due to active laccase was observed against white background.

The above study holds a high potential for the use of Pleurotus sajor-caju for laccase 
production from cheap biomass. Moreover, Pleurotus sajor-caju being an edible mushroom will have no toxicity, and SSF can be directly used as enzyme containing animal feed supplements.

\section{SUPPLEMENTARY INFORMATION}

Supplementary information accompanies this article at https://doi.org/10.22207/JPAM.15.2.54

Additional file: Additional Figures 1S- 7S.

\section{ACKNOWLEDGMENTS}

The authors are grateful to DBT, New Delhi, India for financial support and to Professor Paresh R Pandya, Anand Agricultural University for analysis and biomass.

\section{CONFLICT OF INTEREST}

The authors declare that there is no conflict of interest.

\section{AUTHORS' CONTRIBUTION}

Both listed authors have made a substantial, direct and intellectual contribution to the work, and approved it for publication.

\section{FUNDING}

This study was funded by DBT, New Delhi, India under grant No BT/PR9662/AAQ/1/582/2014

\section{DATA AVAILABILITY}

All datasets generated or analysed during this study are included in the manuscript.

\section{ETHICS STATEMENT}

The article does not contain any studies with human participants or animal performed by any of the authors.

\section{REFERENCES}

1. Ashokkumar P. Optimization and purification of laccase from Pleurotus sp. and its dye decolorization ability. $J$ Acad Indus. 2012;1:39-44.

2. Bagewadi ZK, Mulla SI, Ninnekar HZ. Optimization of laccase production and its application in delignification of biomass. International Journal of Recycling of Organic Waste in Agriculture. 2017;6:351-365. doi: 10.1007/s40093-017-0184-4

3. Bhargav S, Panda BP, Ali M, Javed S. Solid-state fermentation: an overview. Chemical and Biochemical Engineering Quarterly. 2008;22:49-70.
4. Cohen R, Persky L, Hadar Y. Biotechnological applications and potential of wood-degrading mushrooms of the genus Pleurotus. Applied Microbiology and Biotechnology. 2002;58:582-594. doi: 10.1007/s00253-002-0930-y

5. De Souza CGM, Tychanowicz GK, De Souza DF, Peralta RM. Production of laccase isoforms by Pleurotus pulmonarius in response to presence of phenolic and aromatic compounds. Journal of Basic Microbiology. 2004;44:129-136. doi: 10.1002/jobm.200310365

6. Dekker RF, Barbosa AM. The effects of aeration and veratryl alcohol on the production of two laccases by the ascomycete Botryosphaeria sp.. Enzyme Microb Technol. 2001;28:81-88. doi: 10.1016/S01410229(00)00274-X

7. Ding $Z$, Chen $Y, X u Z$, et al. Production and characterization of laccase from Pleurotus ferulae in submerged fermentation. Annals of microbiology. 2014;64:121-129. doi: 10.1007/s13213-013-0640-y

8. Eggert C, Temp U, Dean JF, Eriksson KEL. A fungal metabolite mediates degradation of non-phenolic lignin structures and synthetic lignin by laccase. Febs Letters. 1996;391:144-148. doi: 10.1016/00145793(96)00719-3

9. Ayuso-Fernandez I, Rencoret J, Gutierrez A, RuizDuenas FJ, Martinez AT. Peroxidase evolution in white-rot fungi follows wood lignin evolution in plants. Proceedings of the National Academy of Sciences. 2019;116:17900-17905. doi: 10.1073/ pnas.1905040116

10. Fuzy A, Biro I, Kovacs R, Takacs T. Estimation of AM fungal colonization Comparability and reliability of classical method. Acta microbiologica et immunological Hungarica. 2015;62:435-451. doi: 10.1556/030.62.2015.4.8

11. Gayazov R, Rodakiewicz-Nowak J. Semi-continuous production of laccase by Phlebiaradiata in different culture media. Folia Microbiologica. 1996;41:480-484. doi: $10.1007 /$ BF02814662

12. Gervais $P$, Molin P. The role of water in solid-state fermentation. Biochemical Engineering Journal. 2003;13:85-101. doi: 10.1016/S1369-703X(02)00122-5

13. Gianfreda L, Xu F, Bollag JM. Laccases: a useful group of oxidoreductive enzymes. Bioremediation Journal. 1999;3:1-26. doi: 10.1080/10889869991219163

14. Kapoor M, Kapoor RK, Kuhad RC. Differential and synergistic effects of xylanase and laccase mediator system (LMS) in bleaching of soda and waste pulps. J Appl Microbiol. 2007;103:305-317. doi: 10.1111/j.1365-2672.2006.03251.x

15. Klungness JH, Ahmed A, Ross-Sutherland N, Abu-Bakr S. Lightweight, high-opacity paper by fibre loading: Filler comparison. Nordic Pulp and Paper Research Journal. 2000;15:345-350. doi: 10.3183/npprj-200015-05-p345-350

16. Ko EM, Leem YE, Choi H. Purification and characterization of laccase isozymes from the white-rot basidiomycete Ganoderma lucidum. Appl Microbiol Biotechnol. 2001;57:98-102. doi: 10.1007/ s002530100727

17. Koradiya M, Duggirala S, Tipre D, Dave S. Pretreatment optimization of Sorghum pioneer biomass for 
bioethanol production and its scale-up. Bioresource Technology. 2016;199:142-147. doi: 10.1016/j. biortech.2015.08.156

18. Kubicek CP. Fungi and lignocellulosic biomass, in: John Wiley and Sons (Eds.). The plant biomass, United Kingdom. 2013:1-27. doi: 10.1002/9781118414514. ch1

19. Kunamneni A, Ballesteros A, Plou FJ, Alcalde M. Fungal laccase-a versatile enzyme for biotechnological applications. Communicating Current Research and Educational Topics and Trends in Applied Microbiology. 2007;1:233-245.

20. Leonowicz A, Szklarz G, Wojtas-Wasilewska M The effect of fungal laccase on fractionated lignosulphonates (Peritan Na). Phytochemistry. 1985;24:393-396. doi: 10.1016/S0031-9422(00)807347

21. Li F, Ma F, Zhao H, et al. A lytic polysaccharide monooxygenase from a white-rot fungus drives the degradation of lignin by a versatile peroxidase. Appl Environ Microbiol. 2019;85:e02803-18. doi: 10.1128/ AEM.02803-18

22. Liew CY, Husaini A, Hussain H, Muid S, Liew KC, Roslan HA. Lignin biodegradation and ligninolytic enzyme studies during biopulping of Acacia mangium wood chips by tropical white rot fungi. World I Microbiol Biotechnol. 2011;27:1457-1468. doi: 10.1007/s11274010-0598-x

23. Liu S, Dong J, Zhang Y Z. Analysis of Laccase Isozymes from Pleurotus ostreatus. Journal-Sichuan University Natural Science Edition. 2000;37: 71-773.

24. Mansur M, Suarez T, Fernandez-Larrea JB, Brizuela MA, Gonzalez AE. Identification of a laccase gene family in the new lignin-degrading basidiomycete CECT 20197. Appl Environ Microbiology. 1997;63:2637-2646. doi: 10.1128/AEM.63.7.2637-2646.1997

25. Martin H. Review: lignin conversion by manganese peroxidase (MnP). Enz Microb Technol. 2002;30: 454466. doi: 10.1016/S0141-0229(01)00528-2

26. Mitchell DA, Krieger N, Stuart DM, Pandey A. New developments in solid-state fermentation: II. Rational approaches to the design, operation and scale-up of bioreactors. Process Biochemistry. 2000;35:1211-1225. doi: 10.1016/S0032-9592(00)00157-6

27. Mudgett RE. Solid state fermentations, in: A.L. Demain, N.A. Solomen (Eds.), Manual of Industrial Microbiology and Biotechnology. American Society for Microbiology, Washington. 1986:66-83.

28. Niku-Paavola ML, Raaska L, Itavaara M. Detection of white-rot fungi by a non-toxic stain. Mycol Res. 1990;94:27-31. doi: 10.1016/S0953-7562(09)81260-4

29. Patel H, Gupte A. Optimization of different culture conditions for enhanced laccase production and its purification from Tricholoma giganteum AGHP. Bioresour Bioprocess. 2016;3:11. doi: 10.1186/s40643016-0088-6

30. Patil SS. Cultivation of Pleurotus sajor-caju on different agro wastes. Science Research Reporter. 2012;2:225228.

31. Piscitelli A, Giardina P, Lettera V, Pezzella C, Sannia G, Faraco $V$. Induction and transcriptional regulation of laccases in fungi. Current Genomics. 2011;12:104-112. doi: 10.2174/138920211795564331

32. Pokhrel CP, Kalyan N, Budathoki U, Yadav RKP. Cultivation of Pleurotus sajor-caju using different agricultural residues. International Journal of Agricultural Policy and Research. 2013;1:19-23.

33. Revankar MS, Desai KM, Lele SS. Solid-state fermentation for enhanced production of laccase using indigenously isolated Ganoderma sp. Appl Biochem Biotechnol. 2007;143:16-26. doi: 10.1007/ s12010-007-0029-0

34. Risdianto H, Sofianti E, Suhardi SH, Setiadi T. Optimization of laccase production using white rot fungi and agricultural wastes in solid-state fermentation. Journal of Engineering and Technological Sciences. 2012;44:93-105. doi: 10.5614/itbj.eng. sci.2012.44.2.1

35. Saravanakumar K, Saranya R, Sankaranarayana A, Kaviyarasan V. Statistical designs and response surface technique for the optimization of extra cellular laccase enzyme production by using Pleurotus sp. Recent Research in Science and Technology. 2010;2:104-111.

36. Sathesh-Prabu C, Murugesan AG. Potential utilization of sorghum field waste for fuel ethanol production employing Pachysolen tannophilus and Saccharomyces cerevisiae. Bioresource Technology. 2011;102:27882792. doi: 10.1016/j.biortech.2010.11.097

37. Sharma A, Jain KK, Srivastava A, et al. Potential of in situ SSF laccase produced from Ganoderma lucidum RCK 2011 in biobleaching of paper pulp. Bioprocess Biosyst Eng. 2019;42:367-377. doi: 10.1007/s00449018-2041-x

38. Shraddha, Shekher R, Sehgal S, Kamthania M, Kumar A. Laccase: microbial sources, production, purification, and potential biotechnological applications. Enzyme Research. 2011;2011;217861. doi: 10.4061/2011/217861

39. Tanesaka E. Colonizing success of saprotrophic and ectomycorrhizal basidiomycetes on islands. Mycologia. 2012;104:345-352. doi: 10.3852/11-009

40. Thurston CF. The structure and function of fungal laccases. Microbiology. 1994;140:19-26. doi: 10.1099/13500872-140-1-19

41. Tien M, Kirk TK. Lignin peroxidase of Phanerochaete chrysosporium. Methods in enzymology. 1988;161:238249. doi: 10.1016/0076-6879(88)61025-1

42. Viswanath B, Rajesh B, Janardhan A, Kumar AP, Narasimha G. Fungal laccases and their applications in bioremediation. Enzyme Research. 2014;2014:163242. doi: 10.1155/2014/163242

43. Vivekanand V, Dwivedi P, Sharma A, Sabharwal N, Singh RP. Enhanced delignification of mixed wood pulp by Aspergillus fumigatus laccase mediator system. World J Microbiol Biotechnol. 2008;24:2799-2804. doi: 10.1007/s11274-008-9809-0

44. Zadrazil F, Permana IG. Wiesche C. Is the conversion of lignocellulose into feed with white rot fungi realizable? Practical problems of scale up and technology transfer. Science and Cultivation of Edible Fungi. 1999;2:919925. 